\title{
STEFANIA PONTRANDOLFO* Social Mobilities in the Transnational Migration of Romanian Roma ta Italy
}

Intersections.EEJSP

4(2): 126-148.

DDI: 10.17356/ieejsp.v4i2.381

http://intersections.tk.mta.hu

* [stefania.pontrandolfo@univr.it] (Department of Social and Cultural Anthropology, University of Verona, Italy)

\begin{abstract}
The article can be included in the contemporary debate about the role that transnational migrations play in modifying the European social order. There is general agreement about the fact that, in the modern-day global framework, while transnational migration can improve the living conditions of some, they can also make things worse for others and can contribute to creating new forms of inequality rather than curtailing old ones. Scholars agree that international migration can lead to profound social changes through social remittances or cultural mobilities, but they are skeptical about the possibility of considerable re-stratification both in receiving and origin countries.

The article therefore investigates changes in status within some Romanian Roma migrant networks in Italy based on a set of qualitative and ethnographic data compiled during the European project The Immigration of Romanian Roma to Western Europe: Causes, Effects and Future Engagement Strategies - MigRom.

This article demonstrates how Romanian Roma migration is only able to produce status changes in migration partially, and highlights how these changes are the result of a diverse combination of factors, such as Roma migrants' motivation, ambition, and opportunities, but above all migration policies and anti-Gypsyism in the origin and receiving countries.
\end{abstract}

Keywords: transnational migration; social mobility; Romanian Roma; Oltenia; Italy. 


\section{Introduction: Social Inequalities, Social Mobilities and Transnational Migration}

The aim of this article is to investigate the social transformations induced by contemporary transnational migration by analyzing the case studies of several networks of Roma migrants from Romania to Italy.

This introduction mainly provides an update about the connections between social inequality, social mobility and transnational migration studies, thereby positioning the work from a theoretical and methodological perspective within the scientific debate about these topics.

Social inequalities are constantly increasing in Europe as a consequence of globalization economies and policies (ILO, 2008; ILO, 2016; Harvey, 2005; Navarro, 2007). A number of scholars have highlighted how, in this context, transnational migration constitutes one of the main exercises of agency of more vulnerable populations (e.g. Kaneff and Pine, 2011). However, scholars have also accentuated how transnational migrations are processes based on inequality and discrimination, or in other terms, how the right to be mobile is now more selective than ever (e.g. Bauman, 1998). Faist (2014) recently underlined the urgent need for critical reflection and empirical studies about what he defines as 'the European transnational social question.' Within the framework of today's increased flows of people, capital, objects, ideas and practices across national borders (Appadurai, 1996) that are influenced by neoliberal policies and economies, reflecting on the role that transnational mobility plays in modifying the social structure of Europe has now become essential (Favell and Recchi, 2011; Faist, 2014).

In cross-sectional transnational migration and social mobility studies, what has mainly emerged so far is the significant need to renew this areas of research. Social mobility is a classical and central theme in sociology and almost all the principal authors in this disciplinary field have dealt with it. However, a new approach is now needed to overcome the so-called 'survey paradigm' (Bertaux and Thompson, 2006) that has long been the dominant research model. In fact, for a long time in the history of sociology, social mobility studies were mainly based on national statistics and surveys regarding the occupational status and incomes of men in the working age bracket, and within national employment markets. ${ }^{1}$

The economic and social changes of the last few decades have demonstrated, however, the ineffectiveness of this survey paradigm for including the different realities that have long been invisible to social mobility studies. For example, women (unemployed housewives, part-time workers, temporarily and/or irregularly employed women); young people (unemployed or temporarily and/or irregularly employed); and the elite rich on the one hand and the ever-increasing numbers of poor on the other (which now includes temporary workers and many migrants) (Bertaux and Thompson, 2006; Friedman, 2013).

\footnotetext{
${ }^{1}$ Of the plentiful sociological literature that has been produced through the survey paradigm, I will only mention one classical work in the international context (Goldthorpe and Erikson, 1992), and one for the Italian context (Pisati, 2000).
} 
Furthermore, social inequality also depends on extensive distribution systems and resource stratification and the chance of accessing these. For this reason, we can define poverty as reduced access to resources, and upward mobility as movement towards greater access to these. However, resources can be of various types: economic (e.g. employment), social (e.g. social networks), cultural (e.g. consumption patterns) and political (e.g. recognition). This is why social (im)mobility studies should not merely take figures about the income of one part of the population (such as working men) into consideration. It is necessary to go beyond employment status when studying social mobility and to investigate the social and cultural dimensions that effectively contribute to it (i.e. social network protection, or changes in consumption models that can transmit and favor upward mobility as well as racialization processes that can impede upward mobility, even if incomes increase, etc.).

Several scholars have also underlined how these extensions in the field of study must necessarily be accompanied by a new combination of quantitative and qualitative research methods. Qualitative research should be extended to fill the gap that the survey paradigm leaves by gathering data about less statistically relevant but certainly no less sociologically and anthropologically relevant aspects of reality. A new and more balanced combination of quantitative and qualitative methods could be part of the ongoing analysis of social and cultural change, together with that of macro and micro structural factors, top-down and bottom-up processes, structural violence in exercising power and the coping strategies of those who are systematically excluded from power (Bertaux and Thompson, 2006; Favell and Recchi, 2011). From this point of view, socio-cultural anthropology, and particularly the anthropology of migratory processes, whose approach centers on studying the global/local connection and social and cultural changes in their historical dimensions (Brettel, 2015), can make a significant contribution to the study of connections between social mobility and transnational migrations.

Moreover, from a methodological perspective, it has been underlined how it is equally important to substantially overcome methodological nationalism (Wimmer and Glick Schiller, 2002) in social mobility studies (so far overly anchored in the various national contexts) (Favell and Recchi, 2011; Faist, 2014), and to delve further into particular 'regimes of mobility' (Glick Shiller and Salazar, 2013) currently in force in Europe. This would certainly provide a more complex and more realistic picture of current dynamics.

Studies of the interconnections between transnational migrations and social transformations are in general agreement that the intensification of transnational migration, in a globalization context, has a considerable transformative impact on modern societies (Vertovec, 2004; Castels, 2010). They also generally agree that the consequences of transnational migrations can be positive, negative or ambivalent. In some cases, they can contribute to reproducing or reinforcing established orders (Portes, 2010), while in other cases they can help create new forms of inequality rather than curtail existing ones (Faist, 2014). They can sometimes, at least partially, lead migrants to successfully achieve their goals of improving their own living conditions (Kaneff and Pine, 2011), often after a long process involving later generations than those that originally migrated (Portes, 2010). 
Migration-induced social transformations may be considered in terms of behavior and value changes, as well as in terms of societal re-stratification and power re-distribution (i.e. the re-organization of socioeconomic status order and hierarchy in both the origin and receiving countries). Scholars agree about the possibility that international migrations can lead to profound social changes through social remittances (Levitt, 1998) or cultural mobilities (Salazar, 2010), but there is more skepticism regarding the possibility of considerable re-stratification both in receiving and origin countries (e.g. Portes, 2010; Castles, 2010). What seems to happen more frequently is not the overturning of the social orders that existed prior to migration, but the consolidation of old orders reinforced by migration (e.g. Lampert, 2012; van Houte et al., 2014) or the creation, through migration, of new stratifications among migrants and non-migrants (e.g. Carling, 2004; Adams et al., 2008).

Scholars who study migration from Romania and who have dealt with the impact of migration on Romanian society thirty years after the onset of migratory flows, which even now regularly involve a significant proportion of the Romanian population, have also come to similar conclusions (Anghel and Horvath, 2009; Anghel, 2010, 2013; Alexandru, 2012).

Studies on Romanian Roma migration also confirm these findings, unfailingly highlighting the fact that Romanian Roma migration is part of the massive post-1990 transnational movement of Romanian citizens (Matras and Leggio, 2018). Some studies in particular have emphasized how Roma actively employ geographical mobility as an instrument for achieving social mobility. The peculiarities of these migrations seem to be having a considerable impact on improving the consumption standards and living conditions of this minority in Romania. These migrants make an enormous collective effort towards desegregation and accessing upward mobility and essential citizens' rights by means of migration. Nevertheless, deep-rooted forms of anti-Gypsyism, both in Romanian society and the destination countries, often impede their progress in terms of status. Real re-stratification on a local level, both in the communities of origin and destination, seem to be very difficult. More frequently, new cleavages are created in the home country within Roma communities and between migrating and non-migrating Roma (e.g. Dion, 2014; Benarrosh-Orsoni, 2015; Anghel, 2016; Toma et al., 2018). ${ }^{2}$

This article aims to contribute to the debate on transnational migration as a process of social transformation by investigating efforts made towards status changes within some Romanian Roma migrant networks in Italy. The article is based on a set of qualitative and ethnographic data collected during the European research project The Immigration of Romanian Roma to Western Europe: Causes, Effects and Future Engagement Strategies - MigRom. The choice of an ethnographic method was linked to the decision to investigate the connection between migrations and social transformation drawing attention to the grassroots level of social life and to the Roma migrants' own visions of migration and mobility. The choice of method was also linked to the decision to focus on micro- and meso-level processes; that is, on the localized nature of social transformations induced by transnational practices (Fauser

\footnotetext{
${ }^{2}$ Similar observations have been made about Roma migration from other Eastern European countries (Grill, 2012; Benedik et al., 2013; Durst, 2013).
} 
and Nijenhuis, 2016). The privileged point of view that is reported here is therefore that of the country and places of migration where the studies were mainly carried out. ${ }^{3}$

The article dedicates the greatest possible space and weight to stories and experiences as told by Roma migrants encountered during the research effort. Indeed, these Roma's individual trajectories incorporate the widest sociocultural and economic-political scenarios that the study attempts to investigate and understand. The article is based on the conviction that the details in these migrants' life stories are not redundant but instead offer the possibility to extend our understanding of contemporary migration and social mobility dynamics that should not emerge only from institutional, mediatic and political public discourses, which are often simplified and stereotypical. For example, the different impacts of various local immigration policies on Roma migrant social mobility opportunities clearly emerge in the different individual and family trajectories, as do the coping strategies they enacted in an attempt to overcome these obstacles.

In the first part of the article, I introduce the research methods that were adopted and describe the family networks with which the research was carried out. I then provide a short description of Italian local immigration policies and their impact on Roma migration patterns. Next, I introduce five family stories that represent a selection of very different social (im)mobility cases to highlight how status change opportunities can be conditioned by different factors. Among these are the migrants' desires and motivations, but above all local reception policies and levels of antiGypsyism $^{4}$ in both receiving and origin societies. In analyzing these stories, I highlight some trends that I consider relevant to the migratory processes under discussion, such as the negative impact of local policies on Roma social mobilities and the Roma's efforts to overcome obstacles through strategies like 'multifocal migration.'

\section{Methodological notes and description of the fieldwork}

The agreement signed by the MigRom project partners foresaw sharing of part of the data produced by the research among the researchers in their various teams. The aim was to increase the opportunity for confronting and comparing the results of the various national research contexts. More precisely, we foresaw the sharing of a series of semi-structured interviews conducted by researchers with the help of Roma research assistants in the interviewees' mother tongue, and the use of a semistructured and qualitative interview grid that researchers from all the teams compiled together. Consequently, all the MigRom partners shared the following items: audio recordings in the migrants' mother tongue, transcripts in Romani or Romanian, and translations in the national languages of the migrants' reception countries in some of their interviews. The researchers involved in the various national teams collectively

\footnotetext{
${ }^{3}$ Although the MigRom project researchers also carried out several brief ethnographic visits to the places from which Roma migrants in Italy originated (Romania), and also to other migration destination locations, such as the United Kingdom and Germany.

${ }^{4}$ Anti-Gypsyism can overlap and sometimes coincide with reception policies, but cannot be reduced to these. It can be defined, in fact, as a broader 'social, psychological, cultural and historical phenomenon that sees in those it identifies as 'Gypsies', a subject for prejudice and negative stereotypes, discrimination and direct or indirect violence' (Piasere, 2015: 11).
} 
produced part of the data. Therefore, in the case of the Italian team, for example, while the interviews were carried out by Suzana Jovanović and Marianna Agoni with a Roma network in Milan, and by Dainef Tomescu and the current author with a Roma network in Bari, and by Angela Petre and Sabrina Tosi Cambini with a Rudari network in Florence; the aforementioned researchers, together with team coordinator Leonardo Piasere and other researchers involved in the project, contributed to defining the interview grid, identifying persons for interview, transcribing into Romani or Romanian, translating from Romani or Romanian to Italian, and the initial analysis of content. Interviewees were not selected on the basis of predefined sociological variables (such as gender or age), but rather by snowball sampling; that is, by following the interviewees' social networks as revealed by ethnographers embedded in the field. This collaborative work is now reflected, for example, in how I have cited some interviews carried out in Milan in some of my articles, and the fact that interviews I did in Bari are referenced in my colleagues' work (see, for example: Jovanović et al., forthcoming). Other data collected on an individual basis (other interviews or purely ethnographic data) are, however, used singularly in the work of each individual researcher. The Italian team shared six interviews in Romani collected in Milan, four interviews in Romani recorded in Bari, and five interviews in Romanian collected in Florence within the Italian team and with the other MigRom project teams. This article specifically includes some data from the shared interviews conducted in Milan and Bari and ethnographic data collected during the author's individual fieldwork.

This article is therefore based on data collected during fieldwork with two Roma family networks originating from Oltenia (Southwestern Romania), who migrated to Milan (North Italy) and Bari (South Italy) and with whom a significant part of the MigRom research was conducted by the Italian study team between April 2013 and December 2015.

The first part of the fieldwork produced a series of semi-structured interviews in the Romani language conducted by researchers Marianna Agoni and Suzana Jovanović in Milan and the Milanese hinterland with a network of Roma families originating from some villages and small towns in the district of Olt. Some of these families live in extremely precarious conditions in tents and makeshift huts in informal settlements that are constantly dismantled and rebuilt in the north-western suburbs of Milan. Others, after a lengthy experience of similar housing conditions, are currently living in rented houses or accommodation provided by private social associations in Milan.

The second part of the fieldwork produced some semi-structured interviews in the Romani language conducted by Dainef Tomescu and myself and an ethnographic study that I carried out in Bari with a network of Roma families from the city of Craiova (district of Dolj). These families live in the only authorized 'Nomad camp' in Bari and have therefore been living in reasonably stable conditions for over ten years.

They are, therefore, two different family networks who both define themselves as Roma, but whose identity refers mainly to the density of parental, friend and neighbor relations that existed in their places of origin in Romania and which they have maintained or recreated in their respective migration zones in Italy. Two family networks that, while both from different places in Oltenia, share a similar historical and geo-political background, as well as similar initial migratory experiences 
(Pontrandolfo, 2016). The reasons for migration were those most common to all the members of both social networks.

Interviewees affirm that their migratory experience started at the end of the 1990s (from 1997 to 2000). In their opinion, the economic crisis inherited from the Ceauşescu regime, worsened by Romania's entry into a free market system (in the political framework of a weak and young democracy), was the decisive push factor for their migration towards Western Europe. Another important push factor, in their words, was the desire 'to be like the others', ${ }^{5}$ that is, to drag themselves out of a situation of need and poverty, provide for their families, and improve their living conditions in Romania by, for instance, buying or building themselves a house. Nevertheless, some were motivated by a desire for social equality that cannot be interpreted purely in terms of income. Through the recurring expression of the desire 'to be like the others', these Roma underline that their migration is an attempt to withdraw from systematic exclusion from enjoying the rights of fundamental citizenship in its social (e.g. right to a house and job, access to social services healthcare, education, etc.) and political dimensions (e.g. participation or recognition of cultural diversity), both in their own country and in the country of destination. The desire 'to be like the others' should therefore not be interpreted as a desire to no longer be Roma, but rather as a desire to access the rights guaranteed to all other citizens while still maintaining their own cultural Roma identity.

Although the aspirations and motivations were similar, the two family networks' migratory routes in the Italian context turned out differently, mainly due to different local immigration policies.

\section{Immigration policies and Roma patterns of migration in Milan}

$\operatorname{Milan}^{6}$ is a large metropolis with a Roma presence in the total population of 0.3 per cent. Here, the Roma and Sinti groups are highly complex and diverse since they include some members that have been living in the city for centuries, or at least for several decades, and others that arrived only recently or are simply passing through. The group includes Italian, foreign and stateless people, those who live in apartments, the so-called 'Nomad camps', and informal settlements with tents and shacks. There are Roma and Sinti families with different stories, different socio-cultural constructions, and different economic and juridical situations. Despite this complexity, Milan Council's policies regarding Roma and Sinti that have been planned and implemented over the last twenty years have always been based on a homogenizing vision of extremely diverse sociocultural realities. Although the particular administrative categorizations used to define them have changed over the years

\footnotetext{
${ }^{5}$ While the individuals concerned in this article will remain anonymous through the use of pseudonyms, references will often be made to the places, dates, and contexts of extracts from ethnographic interviews and conversations. However, some expressions repeatedly used by many interlocutors during various ethnographic conversations and/or interviews have also been used. Expressions like 'to be like the others' and others are authentic leitmotifs that were repeated so often that I have only inserted them in quotation marks so as not to burden the text with too many references.

${ }^{6}$ For a more detailed account of local policies regarding Roma and Sinti adopted in Milan over the last 20 years, see: Agoni (2018).
} 
(initially 'Gypsies' or 'Nomads', but now 'Roma, Sinti, and Caminanti'), the homogenizing approach, which tends to categorize those affected into a separate group from other citizens and/or migrants, has not.

Faced with problems substantially linked to the harsh living conditions of some populations that had migrated to the urban territory (recently, predominantly Romanian Roma), the Milanese authorities responded by either activating emergency reception provisions or evicting migrants and driving them away, and seldom resorted to the use of ordinary welfare instruments, like social housing, to solve problems. Although the legal provisions did try to activate reception policies as well as expulsion, issues remained. The maximum capacity of reception centers established between 2012 and 2013 was and remains much less than needed, and social housing is not in a much better situation. Therefore, hundreds of people still have a housing problem and are forced to undergo the endless evacuations and constant relocations they have been experiencing for years. Just to give an idea of what the eviction policy in Milan implies: from 2013 to 2015, 1284 people were evicted, with an average of 1.3 evictions a day.

In terms of dwelling conditions, some of these Roma families from Olt live in tents and huts in informal settlements in the Northwestern outskirts of Milan, while others live in temporary reception centers set up by Milan Council. Others, often with the help of third sector associations, have managed to rent an apartment.

Almost all the Roma families living in informal settlements practice a temporary and circular type of migration featuring frequent round trips between Milan and their villages of origin in Romania. This circular pattern is strongly conditioned by local policies, which make it almost impossible to have a permanent arrangement. Living in an informal settlement indeed means living in extremely precarious conditions, constantly waiting for the next eviction, no matter how much the Roma try to make it a homely place to live in. This is why, in the majority of cases, families leave their children in Romania when they migrate. It is usually the adult members of extended families that alternate stays in Milan and Romania so that there is always someone in Romania to take care of the children, house and land. The harshness of life in a makeshift hut and tent camp is accepted and acceptable only as a temporary strategy for sustaining the family. In fact, these families usually spend some months in Italy, interrupted by some stays in Romania. The decision to leave is often due to frequent evictions, especially when people lose all their belongings and the law enforcement authorities continue to search for them around the city, preventing them from making a new arrangement. These individuals have lost count of the number of evictions they have experienced over the last 20 years. Despite this, they still persist in coming to stay in Italy. They consider their migration to Italy as a temporary but necessary phase of their existence that will end, sooner or later, with their definitive return to Romania. In

\footnotetext{
${ }^{7}$ Figures issued by Milan Council's Security and Social Integration Office, the Local Police and the Civil Protection and Voluntary Service Association on evictions and expulsions. See for example: Campi Rom, dal 2013 quasi uno sgombero al giorno a Milano (English: Roma camps, since 2013 almost a daily eviction in Milan), 6 November 2015, available at: www.ilgiorno.it/milano/campi-rom-sgomberi1.1458920; Oltre venti favelas eliminate in tre anni (English: Over twenty favelas eliminated in three years), 7 November 2015, available at: http://ricerca.repubblica.it/repubblica/archivio/ repubblica/2015/11/07/oltre-venti-favelas-eliminate-in-3-anniMilano01.html?ref=search.
} 
reality, despite their desires to fulfill their plans to return, migration often remains fundamental for sustaining the family's daily life, both of members living in Milan and those still in Romania. In this way a definitive return to Romania is continually postponed and migrants continue to spend a good part of the year in Italy.

The highly restrictive limits that local policies impose on these families' agency in the migratory context can also be clearly seen in comparison to the situation of those families that live in more stable conditions. The fact of living in social housing or rented apartments and, with varying degrees of stability, being integrated in the employment market with children enrolled in schools in Italy, changes the way in which these families see their migration and plans for the future. According to respondents, as time passes by, trips back to Romania become less frequent and the definitive return is postponed.

\section{Immigration policies and Roma patterns of migration in Bari}

Bari $^{8}$ is an average city with a Roma presence of about 0.1 per cent of the total population. In the last 20 years or so, the Bari local authorities have had to deal with the presence of Roma groups, each very different, but mainly originating from Romania. Relational histories between the various communities and the local authorities are all different and experiences have varied, but the first dealings between Bari Council and Roma occurred when the number of the latter group within the city territory was considerably smaller than today (about 30 people in 1999 and around 80 in 2007). This situation probably helped in activating direct negotiations between those Roma families and public administration, something which at the time of my research seemed much more difficult to achieve. From 2007, new communities began to make their way to the Bari area, some from the same parts of Romania (from Southwestern Oltenia), others from different areas (from Northeastern Moldova). While the council opened its first authorized Roma camp in 2007 to host the pioneering migration families, further informal settlements, both large and small, sprang up here and there in the city, some more permanent and some more visible than others.

Bari Council's center-left administrations have made a variety of public interventions aimed at the social inclusion of the families who currently live in the only council-authorized Roma camp. However, the same administrations have instead appeared indifferent to, or have merely 'tolerated' those who arrived after these pioneer families. In contrast to what happens every day in Milan, the administrative tool of eviction has only been adopted in Bari in exceptional cases over the last 20 years. So, even if many of the families that arrived in Bari about 15 years ago still live in informal settlements or in the authorized camp, they do so without the constant nightmare of being evacuated at any moment, something that contributes greatly to the relatively positive activation of projects for migrant families.

The migrant Roma from Craiova have had the possibility to appropriate the area conceded by the city council and autonomously organize their lives within it.

\footnotetext{
${ }^{8}$ For a detailed reconstruction of the history of relations between the various Roma communities and Bari public administration, see: Pontrandolfo (2018b).
} 
This stability of living has led to an increase in the life opportunities of inhabitants, mainly by giving them a greater chance of finding work which includes a combination of various economic practices: among these, the creation of a Roma cooperative society (operating in the cleaning and clearance sector for small removals, goods transportation, gardening, and material recovery) has proved to be one of the most advanced successes of the inclusion initiative in Bari.

Housing stability (despite all the limitations in terms of segregation and inconvenience that a settlement of self-built huts can have) for about 10 years in the same place has also allowed families to reunite with some of their extended family members. The Bari camp is made up of a set of related families who, over the years, have gradually joined the families who first set out to migrate to Bari. Furthermore, over time, parents, with all their children, have arrived to join their families. While in the initial phases of their stay in Italy these families left their children in Romania (as many migrants in Milan who live in informal settlements still do), once allowed to stay in the authorized camp in Bari they were joined by all their family members. Moreover, as of that moment, many children have been born in Bari and are growing up immersed in an Italian sociocultural lifestyle through which they also acquire different expectations than those of their parents. Many of them, once they have come of age, decide to migrate to other countries in search of better living conditions than those experienced in Italy.

\section{Migration stories}

In this section, I synthetically report some of the stories told by the Roma migrants in Milan and Bari. The former either live, or have lived, in informal settlements, reception centers, rented houses, and the council-authorized camp in Bari. Each story shows some of the variety of ways in which migration and mobility paths can unfold. The stories selected here, although not 'representative' of others, certainly have many features in common with other stories collected during the fieldwork because, to various extents, they encapsulate the same political, economic, social, and cultural scenarios. All of these stories actually show how individual and family experiences are subject to the influence of particular factors, such as the migrants' particular motivations and aspirations; the duration of their migratory courses; reception policies in Italy with their consequences in terms of migrants' increased visibility and marginalization; and relations between their status in Italy and in Romania.

Below are five stories reconstructed on the basis of their protagonists' narratives. My analysis of these stories can be found in the underlying paragraphs where I mainly highlight the relevance of each story from the point of view of social mobility and migration-induced transformations - all this in the awareness that each story includes much more information both about the complex life paths of these individuals and on contemporary migratory dynamics. It is, however, important to underline how often the desire 'to be like the others' came up in interviews and in ethnographic conversations, or, more generally, how often the topic of social mobility spontaneously emerged in the words of our interlocutors in the field. The interview grid, for example, did not actually foresee specific items of social mobility, yet repeated 
references to this topic in the words of the Roma migrants we met in the field obviously show its importance from their point of view, as the stories below attempt to highlight.

\subsection{Mihai and Nadia ${ }^{9}$}

Mihai and Nadia are about 30 years of age and have four children. They arrived in Milan from a small town in the district of Olt. Before migrating, which occurred after Romania became a member of the EU, they coped by doing a variety of casual jobs for other Roma or gağé. ${ }^{10}$ In Romania, they were among 12 people living in a small house 'made of clay' belonging to Mihai's parents. At the time of the interview, they were living in a hut in an informal settlement on the outskirts of Milan. They had always lived in this - constantly evacuated - type of settlement since they began their circular migration in Italy. They had stayed in a reception center for a short period but had been moved on from there apparently for not having respected the obligation of sending their children to school (due to the lack of flexibility of the bureaucratic school enrolment mechanisms), and for having taken Mihai's mother (who had come from Romania for surgery) and one of their daughters (who had been staying with her grandmother in Romania) into the center without the consent of the organizers. Unstable living conditions and irregular earnings from mangimós ${ }^{\prime \prime}$ have not allowed them to improve their initial conditions very much at all (it takes a great deal of effort and energy even to find enough money to travel home), but in Italy, at least they manage to eat.

M: In Romania [...] I worked as a day laborer [...], I earned money for food but it wasn't enough, then [...] we said: 'Let's go, too, so that we can sort ourselves out' [...]. And yet here it's even worse... [...] We thought we would have lived better, but nothing has changed, nothing, nothing! We left the rubbish heap and we returned to the rubbish heap!

\subsection{Octavian and Adina ${ }^{12}$}

Octavian and Adina are about 30 years of age, have three children and come from a small town in the district of Olt. Before migrating, they worked with their families as seasonal farm laborers until mechanized farming vehicles in the area made the work of so many similar casual laborers superfluous. As Octavian says, 'there's a lot of technology now, and this technology has left men without work.' Octavian came to Italy in the wake of his father before getting married. With money from mangimós

\footnotetext{
${ }^{9}$ Interview, Milan, 26-06-2014.

${ }^{10}$ Non-Roma in Romani.

11 Non-Roma generally translate the Romani word mangimós as 'begging.' However, according to a number of Roma, mangimós refers to a set of activities that also includes various forms of exchange. A widespread form of mangimós that families in Milan and Bari practice is, for example, begging at supermarket entrances, but they also receive donations from charitable organizations in the form of food, clothes, school equipment and so on.

${ }^{12}$ Interview, Milan, 18-12-2013.
} 
in Italy, they managed to re-build his father's old house and, above all, put together the bride-wealth for his marriage to Adina. Once married, in 2004 Adina and Octavian decided to set off for Italy together without a valid residency permit. They lived in informal settlements on the outskirts of Milan for years practicing, from 2004 to 2007, circular migration and surviving essentially on mangimós, leaving their children in Romania with their paternal grandfather and aunts and uncles with whom they alternated their circular migration. From 2007 to 2012, Octavian worked semipermanently for a building demolition cooperative, even if contracts were either informal or on-and-off. In the same period, Adina, with the help of some Italians she met during mangimós, began to find some non-declared jobs as a housemaid. The earnings from these jobs were not enough to allow them to leave their life in the informal settlements, but they did allow their children to join them in Italy, and they were able to build a new house for everyone back home. In 2012, the fatigue of years of living precariously, difficulty of staying in constantly evacuated informal settlements and the desire for regular jobs led Adina and Octavian to accept, after the umpteenth evacuation, a local institution's offer of housing at a reception center, and to start an employment integration courses that the council proposed. At the time of the interview, Adina and Octavian had been living for two years with their children in one room in a kind of large container divided into several rooms in which other Roma families also lived. The children were all enrolled at school, even the youngest had just started playschool. Nevertheless, both Adina and Octavian were out of work. Within the first few months of their stay at this place, Octavian accepted a training/work experience course at a bakery with the idea that he would be taken on full-time at the end of the course. Adina also started a sewing course, but both soon regretted these decisions. Octavian did not receive a salary for the training course but was instead paid in food vouchers, and the bakery was a two-hour drive from home every day. When he could no longer use the car (sequestered due to a lack of insurance) and, above all, when it became clear that the bakery had no intention of employing him at the end of the training course, Octavian stopped going. At that point, he once again found himself having to resort to mangimós. Life had certainly been hard when they were living in informal settlements, but at least they were free to find profitable work, even if it was non-declared.

S: Compared to when you left Romania at the very beginning, is your situation better or worse now?

O: To tell you the truth, in these last two years or so, we have gone backwards. From 2007 to 2011 things were going very well. I was working and I built the house...

A: We were fine while we were in the camp... [...] Now we are telling these people 'It's your fault that we lost our jobs! We had work while we were living in the camp, we built a house, look, I'll show you...', and they tell us 'Ah yes, you had money in the camp, but you didn't have a house, you didn't have electricity, heating!'. And I tell them, ' Yes, but you come to Italy to build yourself a house, not to live in Italy forever!' 'Ah, but we give you free food, you live without paying, you don't pay anything!' And with that they shut us up! 
O: They say: 'As you were living in the camp, you can live here just the same, while at the camp they kept turfing you out!' This is the problem. They keep turfing you out, sending you away. This is the problem, because, if it weren't for the evacuations, we were fine there and when we went home, we had our own houses...

\subsection{Sabin and Ana ${ }^{13}$}

Ana and Sabin are about 30 years old and come from a village in the district of Olt. Before migrating, both earned their livings as day laborers on farms and were often paid in goods, such as flour or corn cobs, instead of cash. Sabin began circular migration to Milan, Italy in 2001. In 2005, the couple managed to build themselves a small house so that Ana and her three children could move from her father-in-law's house into their new home. Ana initially lived alone for long periods and then with her three children as they came along, until 2011. At that point, she began insisting on reuniting the family since they were all suffering from being apart. Sabin, who had always lived in informal settlements in Italy, had tried to keep the family in Romania for as long as possible so they would not have to experience the hardship of living in this type of camp. In fact, when Ana arrived in Milan with their three children, she was indeed shocked that all five of them had to sleep in one tent. After three months, during the first evacuation, Ana together with the children agreed to go to a community for mothers and children in the Milanese hinterland, where they stayed for seven months. Sabin went to live in another informal camp by himself. After this new experience, however, with the help of a third sector association, they managed to rent an apartment on the second floor of a small house in a village in the Milanese hinterland. They are currently waiting for a reply regarding the assignment of a council house in Milan. Sabin has managed to maintain his family, buy a house in Romania, and pay the rent on his current home because he has always worked, even if intermittently, in the building sector. Ana has also managed to find various jobs as a housemaid for Italian families with the help of people she met when she was living in the mother and child community.

S: We have had a very hard life, really tough. It's still tough but at least it's more liveable now, we have more hope. You see, I have done 4-5 hours' work today so I know that, either tomorrow or the next day, I will get the 20-30 euros I earned today, and so I know the children will be all right because, with 30 euros, I can do the shopping and we'll have enough to eat for two or three days and we'll be okay [...]

Our children have grown up, I have been here for many years, now she has got used to it. Okay it's not so nice here but we do find some work, every now and then someone helps us, some gağé... [...] we have more chance of survival here, while in Romania, we have no chance at all... [...] At the beginning we thought we would go back because all my family is there. I thought I would be away a year or a few months and then go

\footnotetext{
${ }^{13}$ Interview, Milanese hinterland, 28-09-2013.
} 
back [...] from 2002-2003. Until almost 2010, I was going backwards and forwards. I would stay in Italy for one, two, three months and then go back to Romania. I stayed there one or two months and then came back here. I don't do that anymore. My children are here now, I have my family here... [...] they go to school, they're doing well, they are getting on well here in Italy. It's a good thing for them to be here, they have everything they need. Why should I go back to Romania?

\subsection{Dan and Lavinia ${ }^{14}$}

Dan and Lavinia are about 50 years old and came to Italy in 1999. They were among the first to migrate to Bari. They had a house in Romania in the tigania of Craiova (district of Dolj). During the Ceauşescu regime, they had always worked with their families in farming cooperatives and a hand-made brick business, combining these jobs with other informal activities like rearing animals and selling textiles and clothes at markets. Before coming to Italy, Dan had tried commuting between Romania and Serbia for the so-called suitcase trade and Lavinia had been in France for a while supporting herself with mangimós. Together, they had also spent time in Madrid, Spain. Their arrival in Italy during a period when crossing the frontier was considerably limited, had cost them about six million lire (corresponding to about 3,000 euros now). To repay the loan they had taken out at the time of departure, they had had to give their home to the Roma who had lent them the money. They had four children at the time of their arrival in Italy but had left with only their two middle daughters, leaving their oldest daughter and youngest son in Romania with their paternal grandmother. Their arrival in Bari coincided with a season of bargaining with the local authorities, which established Dan in the role of political representative for his community, fundamentally made up of a network of Dan and Lavinia's siblings, and the creation of the only camp authorized by Bari Council, in which the community currently lives. The setting up of the camp in 2006 meant that the families of all the camp's inhabitants, including the children that had initially remained in Romania, were able to join them and several other children were born in Bari. Dan and Lavinia's fifth child was born there.

They have lived in Bari for several years. Dan has undergone various training courses as a cultural mediator with temporary contracts with some local institutions. Together with other Roma in his network, he founded a social cooperative which allowed him to live well for many years before the current crisis led to a decrease in work.

In recent years, Dan and Lavinia have been able to buy another house in Romania and even buy land on which to build a house for their children.

The effect of the economic crisis on the cooperative, and a stalemate situation in political relations at a local level (meaning that interventions to improve the living conditions at the camp cannot be foreseen in the near future) have recently forced the couple to ask other Roma in their network for a huge loan to make a different

14 Interview with Dan, Bari, 29-11-2013; Interview with Lavinia, Bari, 02-12-2013; Ethnographic fieldwork in Bari since 2013. 
investment: the migration of their eldest son (with wife and daughter) to the United States.

D: We spent a long time in Romania this summer, much longer than usual, because we needed to sort out documents in the offices there. At the beginning, I was happy, I liked to see things again, people, but then, after a while, I realized that [...] I was bored ... Always the same things, always the same people, always the same questions... I could never go back to live in Romania, I can only go there for a holiday [...] I bought the house there purely because it cost less. I couldn't do it in Italy... But I just can't see myself going back to live there now... (Bari, ethnographic conversation, December 2015).

L: We have asked for a loan so that Viorel can go to America! I hope it all goes well! If we have invested, it is because we hope he can do well there and manage to call us for a reunion in the future... (Bari, ethnographic conversation, March 2016).

\subsection{Ioana and Marcel $^{15}$}

Ioana is Dan and Lavinia's second daughter. She is about 30 years old but she joined her parents in Italy, in Bari, when she was nine. She went to school in Italy and obtained a secondary school diploma, and then she married Marcel. Her husband also came to Italy as a child, migrating to Sardinia with his family of origin. He met Ioana during a trip to Bari to visit relatives and they married shortly after. They lived together in the Bari camp for over 10 years and had three children. Marcel always worked with the Roma cooperative his father-in-law founded, combining this work with other casual labor in the car demolition sector. Following the cooperative's recent crisis, the couple decided to leave Bari and go and live in the United Kingdom in an area of Greater Manchester. They moved in the summer of 2016 and their fourth child was born there. They now live in a terraced house in the UK, which they rent from its Pakistani owner, and Marcel works regularly in an Indian restaurant. With the savings Marcel has been able to put by with his job and benefits from the British welfare system, the couple were soon able to buy a house in Romania.

I: I came to Italy in 2000. I went to school and had a few problems because I was a Romní. I suffered from several episodes of racism until my father began to work. He eventually got sorted and worked at a church [...] They look on us a little better now... [...] I'm getting on well now, but there was a really bad period. It's better now though because I'm used to it, I'm 'naturalized, ${ }^{16}$ I've been here for 13 years and it's like home [...] Yes, because when I go to Romania, I only go to visit. When I

\footnotetext{
${ }^{15}$ Interview with Ioana, Bari, 02-12-2013; Ethnographic fieldwork in an area of Greater Manchester (2017).

${ }^{16}$ Ioana has not officially been granted Italian nationality but she feels like a 'naturalized' Italian.
} 
go there, Romania is a foreign place for me. I grew up here, I'm 'naturalized.' My home is here (Interview, Bari, 02-12-2013).

M: Since we've been in Manchester, a year and a half now, I have managed to do what I wasn't able to do in Italy in 10 years! (Greater Manchester, ethnographic conversation, January 2017).

\section{Analysis of the stories: changing statuses in transnational migration}

As the above stories clearly show, in some cases, the only thing that Roma migrants' efforts to improve their life conditions and status achieve is to ensure sustenance for their family members. The case of Mihai and Nadia is one which can be defined as migration for subsistence (see: Toma et al., 2018). The former left the tigania in their home town in Romania with very few means and it is significant that they only had the chance to do so after Romania became an EU member state. Before that it would have been too expensive. They therefore left with a low status that their migration to Italy has not improved, either in Italy or in Romania. If possible, their status in Italy has become even lower due to their marked visibility and, therefore, their greater exposure to discrimination to which they are subject by living in constantly evacuated informal settlements in the Milanese suburbs.

In other cases, however, things have gone better. Octavian and Adina come from the same tigania as Mihai and Nadia, but their migratory path has lasted longer. They are still highly visible in their destination country but they have been able to achieve some of their objectives: Octavian managed to build a house for his father and to scrape together the necessary amount of money to marry Adina. The couple were later able to build their own house. In this case, a reduction in status in Italy corresponded to an increase in status in Romania (a country in which the couple still project themselves into a more or less short-term future). Nevertheless, their experience also says a lot about the fact that paths do not necessarily lead in the same direction. As other studies on social mobility have also highlighted (see: Friedman, 2013), at any moment, for causes beyond the migrants' control, the path of increasing status can come to a dead-end, or even go backwards compared to migrants' previous positioning. For this reason, all paths should be considered from a historical perspective (see: Vermeulen, 2010).

Sabin and Ana's story, on the other hand, tells of a relatively successful experience in which a lengthy migration to Italy took a family from a situation of significant poverty to one of relative ease, from a situation of high visibility and discrimination to one of invisibility and reasonable integration, allowing them to improve their status both in Romania and Italy.

Dan and Lavinia's story is interesting because it allows us to reflect on the fact that sometimes the solidarity of a group can mitigate the effects of spatial segregation and high visibility. The decision to live together in a Roma camp, in agreement with Bari's local institutions, ${ }^{17}$ allowed the network of families gathered around Dan and

\footnotetext{
${ }^{17}$ For a detailed reconstruction of these families' negotiation processes with the local Bari authorities, see: Pontrandolfo (2018c).
} 
Lavinia's family to cooperate and help the members along their migratory paths. When these families were able to work, they managed to make investments in houses, land, and cars which, in turn, allowed them to maintain a higher status than in Romania in the past, even if their status level in Italy was still relatively low.

Marcel and Ioana's story is a one of migratory success. The family has been able to increase their status in Romania and in the country of destination. This is an extremely interesting case because it once again gives us the chance to highlight how national and local reception policies can affect individual or group migratory paths. In fact, in order to increase their status, the couple were forced to leave Italy and go to a country where anti-Gypsyism sentiments are weaker and where reception conditions provide greater invisibility and integration. ${ }^{18}$

Each of these stories, while only truly representative of itself, is not unique. Many Roma families I met in the field live in similar conditions and all were incessantly making every effort to improve their own position. These efforts are strongly affected by their (un)stable living conditions. Migrants who are not allowed to settle permanently in one place long enough to achieve their social mobility goals find themselves in the most difficulty. This mobility depends on ample resource stratification systems and opportunities to access them. Resources can be of various types: economic (e.g. employment), social (e.g. social networks), cultural (e.g. consumption patterns) and political (e.g. recognition). Each of the stories I have presented here could be analyzed in terms of the variable results obtained from accessing different types of resources. Here, I mainly consider access to resources in terms of material assets and earnings ${ }^{19}$ since the migrants I met in the field have achieved notable results from their efforts in this direction. Indeed, through migration, they have all managed to survive and, for many of them, this level of survival is in line with Italian standards of consumption, which are now thought of as indispensable in Romania (see: Agoni, 2016). Many migrants have managed to buy land or materials to build a house; others have renovated their old houses or built new ones. In some cases, the purchase of a house has also led to spatial desegregation since they have moved from the tigania to an area much closer to the center of the town or city of origin. In some cases, upward mobility has occurred thanks to the possibility of maintaining a job as well as a permanently rented house in the migration destination country.

What seems certain from the stories collected in the field, both in Milan and Bari, is that migration has created new forms of social stratification between migrant Roma and Roma who were not able to leave, or who left later, or who were not away from home long enough, or who, for various reasons, were not able to accumulate enough material capital.

What, on the other hand, is less evident, is evidence for new forms of stratification, both in Romania and in Italy: strong social, cultural and political resistance hinders the emergence of any kind of valid social re-stratification in these countries.

\footnotetext{
${ }^{18}$ Several studies show that Italy is currently the EU country with the highest rate of anti-Gypsyism (e.g. European Commission, 2008; Pew Research Centre, 2014; Meneghini and Fattori, 2016).

${ }^{19}$ Refer to Pontrandolfo (2018a) for a more detailed analysis of the social transformation process in terms of cultural mobilities.
} 
In the areas of Romania from which the migrants we met originate, the visibility of migrants' success in terms of an improvement in their living conditions or in terms of desegregation from the tiganie does not alter the stereotypes that other Romanians hold. The tiganie are still there. And it is also true that, when they can, successful migrants choose to invest in other places, often in a new migration, rather than in their homeland.

Roma migrants in Italy are located in the most marginal brackets of the population, so much so that, after having experienced the impossibility or meagre probability of making significant improvements, those who can try to leave Italy for other destinations: Germany, the United Kingdom, Canada, or the USA, countries whose migration policies offer Roma integration modalities with less stigmatization, ethnicization or racialization.

Last, one of the effects that migrations have had on these two Roma family networks which is important to underline is that they have led not so much to a reduction over time in migration, but rather to an extension and expansion. Currently, many extended families have split up and are living separately in several European countries or in North America. Their transnational condition is not simply 'bifocal' (Vertovec, 2004), but permanently 'multi-focal. ${ }^{20}$ This multi-focal aspect is the most effective way for families to escape from different forms of anti-Gypsyism, both institutional and otherwise, and their consequences. It is therefore the most effective way to access different forms of upward mobility. I believe that these families' ability to remain united, even while living apart in different countries and maintaining enormous multi-focality over time, is one of the aspects of Roma migration that needs to be researched more deeply in the future.

\section{Conclusion}

This article investigated attempts to enhance processes of social transformation and upward mobility through transnational migrations, starting with an analysis of efforts to change status by some networks of Romanian Roma who have migrated to Italy and elsewhere.

Analysis of the qualitative data collected using methods of socio-cultural anthropology reveals some elements that weigh negatively on migrants' chances of modifying the social order and the position of the Roma within them through transnational migration, such as the negative impact of reception countries' local policies and deep-rooted anti-Gypsyism. However, the analysis has also shown how the Roma induviduals continue to constantly apply their agency to overcome these obstacles and fight for desegregation, upward mobility, and access to basic citizenship rights through specific migration strategies, such as those that I have defined as 'multifocal migration.' Even if their efforts have not yet produced any notable restratification either in receiving or origin countries, social remittances and cultural mobilities have been enhanced and individual cases of upward mobility can be

\footnotetext{
20 Other studies have already underlined how the practice of living in families with 'a powder structure', i.e. spread over different territories, has led many Roma groups to maintain themselves as such over time (see, for example: Piasere, 2004; Sutre, 2017; Gamella et al., 2018).
} 
documented. I hope this article will contribute to making their stories more visible and increase the political recognition of their unceasing effort.

\section{References}

Adams, R. H., A. Cuecuecha and Page, J. (2008) The Impact of Remittances on Poverty and Inequality in Ghana. Policy Research Working Papers 4732. Washington DC: World Bank. DOI: https://doi.org/10.1596/1813-945(-4732

Agoni, M. (2016) Etnografia delle migrazioni e degli spostamenti di alcune famiglie di rom romeni tra Grădină e Milano (English: Ethnography of Migrations and Movements of Some Romanian Roma Families Between Grădină and Milan). In Pontrandolfo, S. and Piasere, L. (eds.) Italia Romaní: Le migrazioni dei rom romeni in Italia, vol. VI (English: Romani Italy: The Migrations of Romanian Roma in Italy, Vol. VI). Rome: CISU. 141-158.

Agoni, M. (2018) Politiche locali per Rom e Sinti a Milano (English: Local Policies for Roma and Sinti in Milan). In Pontrandolfo, S. (ed.) Politiche locali per Rom e Sinti in Italia (English: Local Policies for Roma and Sinti in Italy). Rome: CISU. 55-118.

Alexandru, M. (2012) Stories of Upward Social Mobility and Migration in One Romanian Commune: On the Emergence of 'Rurban' Spaces in MigrantSending Communities. Eastern Journal of European Studies, 3(2): 141-160.

Anghel, R. G. (2010) La migration internationale: panacée ou entrave au développement local? Étude du changement social récent dans une ville roumaine de forte émigration (English: International Migration: Panacea or Hindering Local Development? Study of Recent Social Change in a Romanian City of High Emigration). Revue d'études comparatives Est-Ouest, 41(4): 73-96. DOI: https://doi.org/10.4074/s0338059910004043

Anghel, R. G. (2013) Romanians in Western Europe: Migration, Status Dilemmas, and Transnational Connections. Plymouth (UK): Lexington Books.

Anghel, R. G. (2016) Migration in Differentiated Localities: Changing Statuses and Ethnic Relations in a Multi-Ethnic Locality in Transylvania, Romania. Population, Space, Place, 22(4): 356-366. DOI: https://doi.org/10.1002/psp.1925

Appadurai, A. (1996) Modernity at Large: Cultural Dimensions of Globalization. Minneapolis-London: University of Minnesota Press.

Bauman, Z. (1998) Globalization: The Human Consequences. Cambridge: Polity. 
Benarrosh-Orsoni, N. (2015) Des maisonnées transnationales: Une migration rom dans ses routes, lieux et objects entre la Roumanie et la France (English: Transnational Households: A Roma Migration in Its Routes, Places and Objects Between Romania and France). PhD Dissertation, Université Paris Ouest Nanterre La Défence.

Benedik, S., Tiefenbacher, B. and Zettelbauer, H. (2013) Die imaginierte 'Bettlerflut': Temporäre Migrationen von Roma/Romnija-Konstrukte und Positionen (English: The Imagined 'Beggar Tide': Temporary Migrations of Roma/Romnija Constructs and Positions). Wien-Klagenfurt: Drava.

Bertaux, D. and Thompson, P. R. (2006) Pathways to Social Class: A Qualitative Approach to Social Mobility. New Brunswich and London: Transaction Publishers.

Brettel, C. B. (2015) Theorizing Migration in Anthropology: The Cultural, Social, and Phenomenological Dimensions of Movement. In Brettel, C. B. and Hollifield, J. F. (eds.) Migration Theory: Talking across Disciplines. New York and London: Routledge, Third Edition. 148-197. DOI: https://doi.org/10.4324/9781315814933

Carling, J. (2004) Emigration, Return and Development in Cape Verde: The Impact of Closing Borders. Population, Space, Place, 10(2): 113-132. DOI: https://doi.org/10.1002/psp.322

Castles, S. (2010) Understanding Human Migration: A Social Transformation Perspective. Journal of Ethnic and Migration Studies, 36(10): 1565-1586. DOI: https://doi.org/10.1080/1369183x.2010.489381

Dion, S. (2014) Un monde européen, entre changements et mobilités: Une étude ethnographique menée auprès de familles roms roumaines en contexte migratoire, entre la région historique de Crișana (Roumanie) et l'agglomération lyonnaise (France) (English: A European World, Between Changes and Mobilities: An Ethnographic Study of Romanian Roma Families in a Migratory Context, Between the Historical Region of Crissana (Romania) and the Lyon Area (France)). PhD Dissertation, Université Catholique de Louvain-La-Neuve.

Durst, J. (2013) It's Better to Be a Gypsy in Canada Than Being a Hungarian in Hungary: The 'New Wave' of Roma Migration. In Vidra, Z. (ed.) Roma Migration to and from Canada: The Czech, Hungarian and Slovak Case. Budapest: CEU CPS. 203-248.

European Commission (2008) Special Eurobarometer 296: Discrimination in the European Union. Perceptions, Experiences and Attitudes. European Commission. Available at: http://ec.europa.eu/commfrontoffice/publicopinion/archives/ebs/ebs_296_en.p df

Faist, T. (2014) On the Transnational Social Question: How Social Inequalities are Reproduced in Europe. Journal of European Social Policy, 24(3): 207-222. DOI: https://doi.org/10.1177/0958928714525814 
Fauser, M. and Nijenhuis, G. (2016) Migrants' Transnationality, Societal Transformation, and Locality: an Introduction. Population, Space, Place, 22(4): 336-342. DOI: https://doi.org/10.1002/psp.1944

Favell, A. and Recchi, E. (2011) Social Mobility and Spatial Mobility. In Guiraudon, V. and Favell, A. (eds.) Sociology of the European Union. Basingstoke: Palgrave MacMillan. 50-75. DOI: https://doi.org/10.1007/978-(0-230-34390-(0_3

Friedman, S. (2013) The Price of the Ticket: Rethinking the Experience of Social Mobility. Sociology, 48(2): 352-368. DOI: https://doi.org/10.1177/0038038513490355

Gamella, J. F., Beluschi-Fabeni, G., Gómez Oehler, E. and Muntean, V. (2018) Founder Effects and Transnational Mutations: The Familial Structure of a Romani Diaspora. In Matras, Y. and Leggio, D. V. (eds.) Open Borders, Unlocked Cultures: Romanian Roma Migrants in Western Europe. London and New York: Routledge. 83-106. DOI: https://doi.org/10.4324/9781315295770

Glick Schiller, N. and Salazar, N. P. (2013) Regimes of Mobility Across the Globe. Journal of Ethnic and Migration Studies, 39(2): 183-200. DOI: https://doi.org/10.1080/1369183x.2013.723253

Goldthorpe, J. H. and Erikson, R. (1992) The Constant Flux: A Study of Class Mobility in Industrial Society. Oxford: Clarendon Press.

Grill, J. (2012) 'Going Up to England': Exploring Mobilities Among Roma from Eastern Slovakia. Journal of Ethnic and Migration Studies, 38(8): 1269-1287. DOI: https://doi.org/10.1080/1369183x.2012.689187

Harvey, D. (2005) A Brief History of Neoliberalism. New York: Oxford University Press.

Horváth, I. and Anghel, R. G. (2009) Migration and Its Consequences for Romania. Südosteuropa, 57(4): 386-403.

ILO (International Labour Organization) (2008) World of Work Report 2008: Income Inequalities in the Age of Financial Globalisation. Geneva: International Labour Organization, International Institute for Labour Studies. 1-162. DOI: https://doi.org/10.1002/wow3.11

ILO (International Labour Organization) (2016) World Employment Social Outlook 2016: Transforming Jobs to End Poverty. Geneva: International Labour Organization.

Jovanović, S., Agoni, M. and Piasere, L. (forthcoming) Romanó Glaso: Voci di Rom migranti (English: Romanó Glaso: The Voice of Migrant Roma). Rome: CISU.

Kaneff, D. and Pine, F. (eds.) (2011) Global Connections and Emerging Inequalities in Europe. Perspective on Poverty and Transnational Migration. London and New York: Anthem Press. DOI: https://doi.org/10.7135/upo9780857288684 
Lampert, B. (2012) Diaspora and Development? London-based Nigerian Organisations and the Transnational Politics of Socio-economic Status and Gender. Development Policy Review, 30(2): 149-167. DOI: https://doi.org/10.1111/j.1467-7679.2012.00569.x

Levitt, P. (1998) Social Remittances: Migration Driven Local-Level Forms of Cultural Diffusion. International Migration Review, 32(4): 926-948. DOI: https://doi.org/10.2307/2547666

Matras, Y. and Leggio, D. V. (eds.) (2018) Open Borders, Unlocked Cultures: Romanian Roma Migrants in Western Europe. London and New York: Routledge. DOI: https://doi.org/10.4324/9781315295770

Meneghini, A. M. and Fattori, F. (2016) Distinzioni e sovrapposizioni tra romeni, rom e rom romeni: un'indagine psicosociale (English: Distinctions and Overlaps Between Romanian, Roma and Romanian Roma: A Psychosocial Investigation). In Pontrandolfo, S. and Piasere, L. (eds.) Italia Romaní, Le migrazioni dei rom romeni in Italia, vol. VI (English: Romani Italy: The Migrations of Romanian Roma to Italy, Vol. IV). Rome: CISU. 81-108.

Navarro, V. (ed.) (2007) Neoliberalism, Globalization, and Inequalities: Consequences for Health and Quality of Life. Amityville (NY, USA): Baywood Publishing.

Pew Research Centre (2014) A Fragile Rebound for EU Image on Eve of European Parliament Eletions. Available at: http://www.pewglobal.org/files/2014/05/201405-12_Pew-Global-Attitudes-European-Union.pdf

Piasere, L. (2004) I rom d'Europa: Una storia moderna (English: The Roma of Europe: A Modern History). Bari-Rome: Laterza.

Piasere, L. (2015) L'antiziganismo (English: Anti-Gypsyism). Macerata: Quodlibet.

Pisati, M. (2000) La mobilità sociale (English: Social Mobility). Bologna: Il Mulino.

Pontrandolfo, S. (2016) Una cornice di contesto per le migrazioni dei rom dall'Oltenia (English: A Context Frame for the Migration of Roma from Oltenia). In Pontrandolfo, S. and Piasere, L. (eds.) Italia Romaní: Le migrazioni dei rom romeni in Italia, vol. VI (English: Romani Italy: The Migrations of Romanian Roma to Italy, Vol. IV). Rome: CISU. 11-32.

Pontrandolfo, S. (2018a) Romanian Roma Migration to Italy: Improving the Capacity to Aspire. In Matras, Y. and Leggio, D. V. (eds.) Open Borders, Unlocked Cultures: Romanian Roma Migrants in Western Europe. London and New York: Routledge. 107-127. DOI: https://doi.org/10.4324/9781315295770

Pontrandolfo, S. (2018b) Politiche locali per i Rom a Bari (English: Local Policies for Roma in Bari). In Pontrandolfo, S. (ed.) Politiche locali per Rom e Sinti in Italia (English: Local Policies for Roma and Sinti in Italy). Rome: CISU. 19-54. 
Pontrandolfo, S. (2018c) Roma 'Acts of Citizenship': Negotiating Categories and Housing Solutions. In Pontrandolfo, S. and Solimene, M. (eds.) 'Gypsies', 'Nomads', 'Roma': Categorization Processes of Roma and Sinti in Italy. Special issue of Nomadic Peoples, 22: 83-103. DOI: https://doi.org/10.3197/np.2018.220106

Portes, A. (2010) Migration and Social Change: Some Conceptual Reflections. Journal of Ethnic and Migration Studies, 36(10): 1537-1563. DOI: https://doi.org/10.1080/1369183x.2010.489370

Salazar, N. (2010) Towards an Anthropology of Cultural Mobilities. Crossing: Journal of Migration and Culture, 1(1): 53-68. DOI: https://doi.org/10.1386/cjmc.1.53_1

Sutre, A. (2017) Du parcours du monde à son invention: Géographies tsiganes en Amérique du Nord des années 1880 aux années 1950 (English: From the World's Journey to His Invention: Gypsy Geographies in North America from the 1880s to the Early 1950s). PhD Dissertation, Paris: Ecole des Hautes Etudes en Sciences Sociales (EHESS).

Toma, S., Tesăr, C. and Fosztó, L. (2018) Romanian Roma at Home: Mobility Patterns, Migration Experiences, Networks and Remittances. In Matras, Y. and Leggio, D. V. (eds.) Open Borders, Unlocked Cultures. Romanian Roma Migrants in Western Europe. London and New York: Routledge. 57-82. DOI: https://doi.org/10.4324/9781315295770

Van Houte, M., Siegel, M. and Davids, T. (2015) Return to Afghanistan: Migration as Reinforcement of Socio-Economic Stratification. Population, Space, Place, 21(8): 692-703. DOI: https://doi.org/10.1002/psp.1876

Vermeulen, H. (2010) Segmented Assimilation and Cross-National Comparative Research on the Integration of Immigrant and Their Children. Ethnic and Racial Studies, 33(07): 1214-1230. DOI: https://doi.org/10.1080/01419871003615306

Vertovec, S. (2004) Migrant Transnationalism and Modes of Transformation. The International Migration Review, 38(3): 970-1001. DOI: https://doi.org/10.1111/j.1747-7379.2004.tb00226.x 